\title{
Features of Conclusion of Electronic Transactions Requiring a Notarial Certificate
}

\author{
Viktoriia O. Khomenko ${ }^{1,{ }^{*}}$, Oksana M. Krukevych ${ }^{2}$, Maksym O. Hetmantsev ${ }^{3}$ and Yurii Yu. \\ Opanashuk ${ }^{3}$
}

${ }^{1}$ Department of Private Law Problems, Academician F.H. Burchak Scientific and Research Institute of Private Law and Entrepreneurship of the National Academy of Legal Sciences of Ukraine, Kyiv, Ukraine

${ }^{2}$ Department of Criminal Procedure and Forensic Science Institute of Law, Taras Shevchenko National University of Kyiv, Kyiv, Ukraine

${ }^{3}$ Department of the Jurisdiction Forms of Legal Protection of Subjects of Private Law, the Judiciary and Legal Proceedings, Academician F.H. Burchak Scientific and Research Institute of Private Law and Entrepreneurship of the National Academy of Legal Sciences of Ukraine, Kyiv, Ukraine

\begin{abstract}
The urgency and urgent necessity to develop a research topic are due to a number of factors. First of all, the legal community unanimously reached a consensus on the necessity to reform the institution of notaries in the direction of expanding the powers and functions of public and private notaries, increasing the requirements for these participants in the context of the procedure of certification of transactions (contracts) in various fields. The reform of the Ukrainian notary has recently exhausted its potential and positive expectations on the part of civil society, which is only complicated by the progressive situation with the spread of acute respiratory infections caused by the COVID-19 SARSCoV-2 virus. The purpose of this article was to objectively outline the existing problems in the field of law enforcement, related to the peculiarities of electronic transactions that require notarization, with the formulation of author's proposals to improve legislation in this area. The study was conducted using a number of general and special methods, a key role among which was played by comparative legal and statistical-prognostic methods, which were used to thoroughly analyze the current state of affairs in the field of electronic certification of transactions by notaries. As a result of the study, the authors concluded that in the development of the global information society and digital economy, the issue of electronic transactions requiring notarization needs further involvement of both theoretical and scientific research, as well as the development of practical solutions and proposals to improve the electronic interaction system.
\end{abstract}

Keywords: Transaction, a notary, the notary, notarized transaction, digitalization.

\section{INTRODUCTION}

The era of globalization is determined by the strong growth of electronic digital services, which allow implementing without territorial and temporal binding such activities, which until recently could only exist in the offline format. These means of digitalization are also integrated into the system of notarial services, which undergo significant transformations and changes in this connection. Unfortunately, the domestic legislator does not demonstrate consistency in the normative consolidation of the possibility and procedure for notarization of electronic form transactions. Thus, the Law of Ukraine "On electronic documents and electronic document management" of 22.05.2003 No. 851-IV (2003) established that the civil law agreement concluded by creating an electronic document (electronic documents) is notarized in the manner prescribed by law (Article 8 of the Law of Ukraine "On electronic documents and electronic document management"). Instead, the Law of Ukraine

*Address correspondence to this author at the Academician F.H. Burchak Scientific and Research Institute of Private Law and Entrepreneurship of the National Academy of Legal Sciences of Ukraine, Kyiv, Ukraine;

Tel: (044) 286-70-99; E-mail: khomenko8@ust-hk.com.cn
"On E-Commerce" No. 675-VIII of 03.09.2015, adopted 12 years later (2015), on the contrary, states that the effect of this legal act does not apply to transactions subject to notarization or state registration (Part 2 of Article 1 of the Law of Ukraine "On Electronic Commerce"). However, in 2017, the Law of Ukraine "On Electronic Trust Services" of 05.10.2017 No. 2155VIII (2017) states that electronic trust services do not change the order of transactions established by law.

In other words, transactions subject to notarization and/or state registration in cases established by law, are made in electronic form only with the use of qualified electronic trust services and in the prescribed manner (Part 6 of Article 17 of the Law of Ukraine "On Electronic Trust Services" (2017). Therefore, all issues related to the peculiarities of electronic transactions that require notarization remain extremely relevant and important for a comprehensive analytical study and practical development. The study was conducted using a number of general and special methods. First of all, a general scientific dialectical method of scientific cognition was used, as well as special legal methods: formal-legal (allowed in studying the nature and essence of notaries in certifying transactions), 
comparative-legal (helped to identify common and distinctive features inherent in different models of certification functions in different countries of the world), system-legal (by means of which the authors' suggestions on the perfection of an integral system of notarial services have been formulated), etc. A separate role was played by the analytical-statistical method, the involvement of which allowed studying the dynamics of the number of citizens' appeals to notary offices (private and public) on the basis of transactions (contracts) in various fields, primarily related to real estate. The purpose of this article is to objectively outline the existing problems in the field of law enforcement, related to the peculiarities of the conclusion of electronic transactions that require notarization, with the formulation of author's proposals to improve legislation in this area.

\section{ADVANTAGES AND DISADVANTAGES OF INTEGRATION OF DIGITALIZATION TOOLS IN THE SYSTEM OF NOTARIAL SERVICES}

The combinatorial correlation of the information society in combination with the rapid development of information technologies through large-scale digitalization together require new legal mechanisms of interaction between the state and civil society and individual institutions with specific participants in the relevant legal relations. It is worth listening to V.S. Petrenko, who argues that electronic forms of communication, especially social networks and the Internet, have reached such a level of impact on public life that they have become an important source of information and therefore require appropriate regulation when used in civil proceedings (Petrenko 2018). At the same time, as noted in the Basic Principles of Information Society Development in Ukraine for 20072015, Ukraine has its own history of the development of the basic principles of the information society: the activities of the world-famous school of cybernetics; formation in the early 90 s of the last century of the concept and program of informatization; creation of various information and communication technologies and national information and analytical systems of different levels and purposes, etc. (Law of Ukraine No. 537-V 2007).

The avalanche-like transformation of established forms and law enforcement methods in the field of notarial activity leads to the fact that the largest share of information documents is currently in electronic format, which is undergoing new routing due to the widespread use of digital signatures. Multi-vector notarization, its purpose and legal consequences, as noted by I.V. Spasibo-Fateeva, due to the fact that notarial bodies are an integral part of the legal system of any country because the functions performed by notaries are objectively necessary and demanded by society (Spasibo-Fateeva 2013). The registration functions of the notary have always been considered an integral part of the access control subsystem that is inherent in any social system, in which the issue of remote processing of information of national importance is acute. Along with this, the role of the notary has recently increased due to new economic relations, the development of business activities related to the execution and registration of contracts, the creation of various forms of ownership, and the emergence of a large number of transactions previously unknown to Ukrainian law (Shkitin 2008). As V.V. Komarov aptly formulated, the essence of notarial activity, its tasks indicate the public law nature of the notary as a body of undisputed civil jurisdiction, because when performing notarial acts both public and private notaries equally implement all functions of notarial activity: ensuring the indisputability and probative value of documents, assistance to individuals and legal entities in exercising their rights and legitimate interests (Komarov 2012).

According to Chinese researchers, the work of a notary certainly influences the development of the usual course of the business world, as a notary is one of those lawyers who currently guards those fundamental values that are being transformed through the total digitalization of all spheres of human life (Junyu 2020). It is difficult to disagree with this position because after the global lockdown not only private companies were forced to transfer most of their operations to a separate mode of operation, but also government agencies and subsidiary structures also faced the necessity to turn into the plane of remote design and sighting the largest share of their responsibilities. And if at first glance, the general feedback to the new practice of public life is extremely negative, but statistics, on the contrary, show that the state in general and the notary in particular, quite well adapted to today's latest realities. Indicative in this context is the statistical information on the number of notarized real estate transactions. According to many scientists, such statistical information is a kind of marker of a situation in a relevant market. After all, as M.M. Dyakovych aptly emphasizes, the rights to real estate do not arise from the moment of their state registration, but from the moment of notarization of the contract (Dyakovych 2014). 
According to K. Chyzhmar and G. Demkina, the meticulous attention of law enforcement officers to the study of this issue is connected with the endowment of a notary with a certain part of the functions of the state registrar of real estate rights to ensure the proper level of protection guaranteed by the Constitution of Ukraine by minimizing the number of instances, obtaining the information required to perform notarial acts, and introduces the principle of "single window", when a notary himself organizes work with the State Register of Real Property Rights by obtaining the necessary information to perform notarial acts with real estate property and the simultaneous implementation of the procedure of state registration of property rights, which arose as a result of certification of transactions or the issuance of a certificate of inheritance, the subject of which is real estate (Chyzhmar and Demkina 2012).

In general, it is quite indicative from the research point of view, the comparison of official indicators of the number of notarized transactions, for example, in real estate, in different time intervals, which allows analyzing the effectiveness and demand of the relevant type of notarial activity which together demonstrates a comprehensive picture of the situation in the relevant services market. As can be seen from the statistics summarised in Figure 1 below, obtained from open Internet sources (Report on the work... 2020), the number of notarized transactions is progressively increasing every year compared to the previous similar period. For example, in the first quarter of 2018, 116999 real estate transactions (agreements) were certified; for the same period in 2019, this indicator was exceeded by $13.5 \%$ (136385 transactions (contracts) with real estate); naturally, in the first quarter of 2020 , the expected further growth of $11 \% \quad(143,865$ transactions) was demonstrated. If to look at the statistical information on the website of the Ministry of Justice for other periods, the projected annual increase in the number of notary authentically certified transactions (contracts) with real estate in the range of $10-15 \%$ can be clearly seen. Instead, the rapid spread of acute respiratory disease caused by the COVID-19 SARS-CoV-2 virus started in March 2020 somewhat disrupted this well-established business practice in the country. As a result of the quarantine restrictions introduced in the second quarter of 2020, 23663 transactions (contracts) with real estate fewer were certified (3134 fewer by state notaries in the second quarter of 2020 than in 2019, and 20529 fewer by private notaries in the second quarter of 2020 than in 2019).
However, by the end of the year, the situation seems to again show a tendency to significantly exceed last year's figures, at least such conclusions can be reached by analyzing statistical reports for the third quarter of 2020, where the number of notarized real estate transactions again exceeds last year's figures (206081 this year in comparison to 179262 in the past 2019 and 163880 - in 2018). These changes are best traced in the format of a table, which shows slight fluctuations in statistics and, at the same time, the impact of the introduced quarantine restrictions on the overall dynamics of the number of applications to notary offices for real estate transactions (contracts). From the authors' point of view, the explanation for this projected hyper trend is the general revival of civil law circulation and the growth of the market of relevant services, including electronically concluded transactions certified by notaries, which was somewhat suspended during the second quarter of 2020 as a result of the so-called lockdown.

Graphically, statistical fluctuations in the dynamic growth of the number of notarized transactions (contracts) with real estate are shown in the diagram below, which clearly shows the quantitative growth of the total number of notarized transactions during the first quarter of each year and the unexpectedly sharp decline in the second quarter compared to similar periods of previous years, and the subsequent "alignment" of indicators after the removal of the socalled strict quarantine in the third quarter of 2020 in relation to the indicators for the same period in 2018 and 2019 , respectively (Figure 1 ).

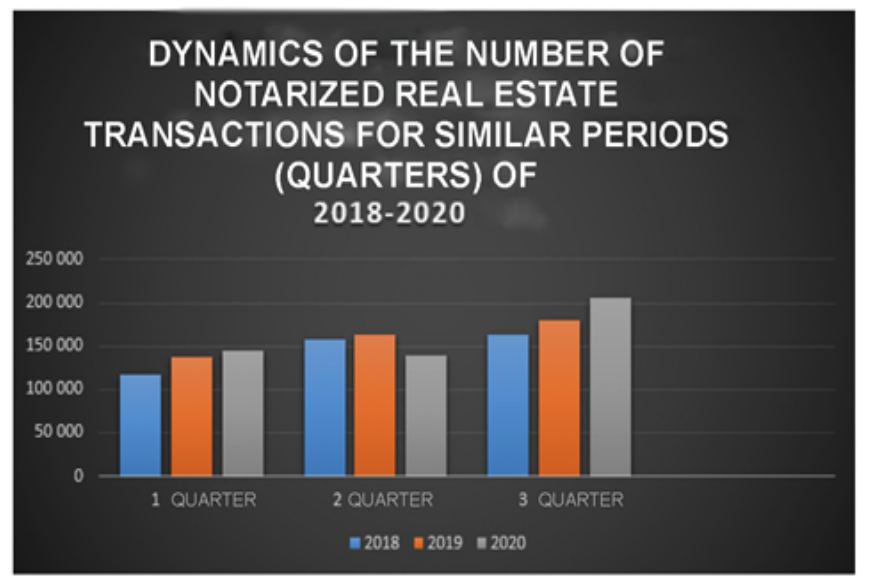

Figure 1: Dynamics of the number of notarized real estate transactions for similar periods (quarters) of 2018-2020.

Note: As the fourth quarter of 2020 was not over at the time of writing, the authors deliberately avoided comparing statistics for this period in previous years.

Source: (Report on the Work... 2020). 
As can be seen, there is a steady trend towards a further increase in the number of notarized transactions (contracts) in the field of real estate, including those concluded using electronic means of communication. Therefore, further improvement of the regulatory framework, which is designed to better regulate these relations, does not lose its relevance due to the fact that modern statistical forecasting methods based on extrapolation of indicators from previous periods to the future, clearly allow simulating a permanent increase in the number of transactions and further. The figure shows that the scope of electronic resources in the notarization of transactions (contracts) is constantly growing because due to the unconditional advantages of digital contracts (efficiency of conclusion, lack of territorial barriers and delays, ease of archival storage of a large number of electronic documents) a way of survival for notaries in situations of quarantine restrictions and a real opportunity to continue to provide their services to all segments of the population. However, it is impossible to ignore a number of difficulties faced by the notarial procedure in the course of digital law enforcement. According to O. Nelin, notaries of Ukraine try to use modern electronic capabilities when performing notarial acts. However, monitoring the use of modern digital technologies by officials of settlement and village councils when performing notarial acts shows that they will never or in the near future be able to transfer applications to legal entities and individuals through software and hardware and the Internet (Nelin 2012).

Along with extremely unsatisfactory logistics, the potential threats from such digitalization of notaries' document circulation should not be minimized, as the recent large-scale increase in the total number of electronic transactions (the lion's share of which are notarized) is also accompanied by an increase in cyberattacks aimed at gaining access to confidential information and relevant registers. In particular, according to the CERT E-Watch Survey for the period 2015-2016, which involved more than 400 commercial and governmental organizations, half of the respondents had negative consequences at least once a year due to leakage of private information, personal or commercial. Moreover, according to Pricewaterhouse Coopers in collaboration with $\mathrm{SHO}$ Media (The Global State of Information Security... 2018)., which surveyed more than 15000 companies in 60 countries (including Ukraine), a third of all violations were triggered by intra-market software shortcomings in the sector.

\section{METHODS OF INTRODUCING ELECTRONIC MEANS INTO THE SYSTEM OF NOTARIAL SERVICES}

Keeping records of access to confidential information, namely, information received by notaries, including in digital format, provides an electronic form of data registration. In order to provide indisputable probative value to such online registration actions, and thus to prevent violations of the law in this area, developed countries practice the introduction of automated addition of information that unquestionably identifies a person in the future to prevent his denial of notarized transactions. In the case of notarization of a transaction by a notary, the latter, as noted by $E$. Daryanti, is responsible for four things: 1 ) identity card (notaries are obliged to clearly identify the parties by signing a contract under someone else's hands, or enter through a legal person (identity card, driver's license, passport) 2) the content of a contract (a notary reads the content of a contract to the parties if they are present in person certificate - does so by means of telecommunications); 3) signature (the parties must sign a contract in the presence of a notary or with the help of a digital signature, which uniquely identifies a person and does not raise doubts about his will); 4) the actual entry of the relevant record of the transactions concluded between the parties in the state register (Daryanti 2018). At the same time, among the relatively new ways of conducting notarial activities, common in foreign countries, as noted by S.Ya. Fursey, the use of electronic signatures and digital information exchange systems in notarial activities is quite common. In particular, in France, there is a special network to which notary offices are connected, thanks to which notaries have the opportunity to exchange the necessary information with each other and with third parties, have access to internal and public databases, offer services with an electronic signature, as well as to the network of the European database, in particular about wills, and to the documents of the European notary (Fursey 2012).

In addition, researchers around the world agree that the best way to verify the authenticity of a notarized transaction is to keep a copy of such a document in a material format. Notarization serves as an aid to establishing the time of existence of the document, assuming that it is relatively difficult to change a notarized document without distorting its content. However, this generally accepted approach is generally not suitable for use with digitally stored documents, as modern legal systems do not yet provide an adequate 
system of protection. For example, the relatively simple task of accessing a saved document to change the numbers, dates, text, and other features of the document is easily accomplished by anyone more or less familiar with the basics of programming and computer literacy. In this case, the counteraction should be the combined use of legal mechanisms with digital technologies, which will allow at the same time keeping a photocopy of the original notarized transaction with its electronic copies (Axelrod et al. 1989). In this context, the register of transactions and rights maintained by notaries acquire new essence and meaning that, according to the point of view of M.B. Zhuzhzhalova, begins to perform a fundamentally different function: in addition to the registration of rights, there is a publicity of contracts, which is an element of the actual composition that is associated not only with the emergence of property rights but also fixing advantages over other buyers (Zhuzhzhalov 2013).

Already in some countries, this postulate finds its practical implementation in many different areas. For example, notarization of wills via open-key cryptographic Internet facilities in medical institutions in developed countries allows patients to exercise full control over their medical data and hereditary mass, and on the other hand allows the state to guarantee full protection of such notarized transactions (Riva, Mandl and Nigrin 2001). The remoteness of the free spread of such practices in the Ukrainian realities is indirectly evidenced by the works of Yu.O. Zaika, whose research concerns mostly hereditary legal relations, but in this context, the scientist noted that quasinotarization of wills in hospitals, nursing homes, correctional facilities, etc. in practice faces numerous legislative conflicts, which in the case of the only notarization easily would be avoided. Thus, according to the scientist's observations, officials of these institutions perform certification actions formally, because a chief physician, for example, does not meet with a patient, cannot check his legal capacity, because he cannot be the attending physician of each department (Zaika 2006). It is noteworthy that this practice is also common under the laws of other countries. For example, in the United States, according to a study by M.V. Bondarev, in addition to notaries, the authority to perform notarial acts by the laws of individual states are given to certain officials, which can be divided into 2 groups: persons whose competence is defined by law and does not require additional confirmation, and persons whose right to perform notarial acts must be confirmed in each case by local regulations (Bondarev 2006).

There are many practical developments on this issue, including taking into account foreign experience. In particular, T. Pashkivska advises Ukraine to adopt the experience of Georgia and some other foreign countries, where the system "Electronic Notary" has been introduced, which allows storing certified copies of citizen's documents on a platform in a personal account. In this case, the fixation and certification of information contained on the sites are used to confirm the terms of contracts, offers, terms of service and their value, as well as sales of goods via the Internet; facts of providing services and their quality (when the content of these services is the creation, maintenance and content of Internet resources); conditions of tenders and auctions for the supply of products and services, conditions of public procurement and other information (Pashkivska 2013). According to O.Yu. Kuzminskaya, the introduction of electronic notaries undoubtedly has more advantages than disadvantages; in addition, most foreign countries have long introduced this system. To introduce e-notaries in Ukraine, it is necessary to amend the legislation, which clearly prescribes what actions can be taken in digital format, which together will increase the availability of notaries for citizens in Ukraine and increase public confidence in this body (Kuzminskaya 2018).

Moreover, non-compliance with such rules and precautions leads to more serious legal consequences, if a person with such a notarized document applies to the court to protect their violated, unrecognized or disputed rights. In such a situation, the restoration of justice will be directly dependent on the notary's compliance with all the above factors of the legality of the transaction certificate. This happened, for example, in accordance with the decision of the Kodyma District Court of Odesa region of 07.04.2015 (Unified State Register... 2015), the claim was denied for recognition of the transaction valid and recognition of ownership of real estate due to the fact that notarized transactions were issued in the Transnistrian Moldavian Republic, and therefore are not recognized in Ukraine. R. Sant'Anselmo analyzed these issues quite thoroughly, noting that the integrated electronic network notary system should include computer subsystems for simultaneous biometric analysis, input and analysis of information about the target object, marking and timestamps with a reliable third-party supplier to ensure the electronic notarial process. The system provides authentication of both signatories and targets. The user 
has the opportunity to either unilaterally certify his signature in a format available to the notary or to cooperate with other entities to achieve the goal of electronic notarization of the target subject of the transaction. The automated notary symbol generator extrapolates a common written notarial symbol by encoding an identifier representing a container of notarial information while affixing the current official time and geolocation data corresponding to the actual event of the notarial certificate (Sant'Anselmo 2018).

So far, the Ukrainian notarization system is still in its infancy compared with developed countries. At the same time, digitalization is not limited to the banal addition of new functionality to existing forms of notarial activity, electronic channels of interaction with clients or exclusively "digitization" of the results of services provided by notaries. However, according to $\mathrm{V}$. Chernysh, the process of transformation of legal systems involves some standardization (universalization) of national legal systems, for which it would be necessary to ensure not only the coordination of legislation and case law but also the identity of views, ideas, concepts, including concerning specific ways and means of construction of the digital operating system of legal certification functions of notaries. Optimization of interethnic interaction of legal systems should not be a set of factual recommendations but should have integrative properties, ensure the interaction of all its components, one of which in the future will be a system of international interaction of the notary (Chernysh 2013).

According to foreign researchers, the compilation of the tradition of electronic-certified transactions faces unique challenges, which include the expression and provision of interaction protocols, control of resource use and prevention of duplication or deletion of contract assets (Das et al. 2018). V.M. Marchenko summarised all these valid arguments and emphasized that the advantages of E-notary apply to all aspects of the notarial process and include both optimizations of the notary's activities and acceleration of the procedure of notarial action, protection of the rights of its participants. The introduction of E-notary will have a comprehensive positive effect, which will be manifested in the simplification of the procedure of notarial acts, as well as storage and exchange of information about the notarial acts (Marchenko 2020). For the development of digital notary, it is necessary to stimulate the creation and implementation of innovative technologies of domestic quality, optimize and bring out the IT sector not only at the level of individual local initiatives but also at the national level, as digitalization of registration procedures has a significant impact on all socioeconomic processes in society.

\section{CONCLUSIONS}

Summing up the study, it should be noted that at the present historical stage it is possible to state the desire of mankind to form radically new ways of functioning of various institutions, including notarial ones, which have long undergone digitalization transformation determined by recently established global quarantine restrictions. At the same time, the large share of urgently introduced digital formats for remote involvement of notaries in the implementation of their registration and certification functions in the country is still at the stage of fragmentary formation with the simultaneous declaration of individual achievements. At the same time, the necessity to optimize the legal mechanisms of interaction between society and a human is still waiting for truly effective solutions both by regulations and by those in power, without the voluntary authorization of which it is currently impossible to introduce new electronic systems for simultaneous remote identification, confirmation of the authenticity of the will and voluntary participation of a subject in the relevant transactions, as well as the parallel signing of a notarized contract by all participants in the legal relationship at the same time.

The development of civil circulation as a legal form and legal reflection of economic correlations is possible only if there is an accessible, clear and effective system of certification of various transactions, including through notarial services in both traditional and online formats. Changes in socio-economic relations, digitalization of social life, and updating of information technologies are positive determinants in the researched issue. At the same time, quarantine restrictions, aggravation of the criminogenic situation in Ukraine and the world, the occurrence of unforeseen emergencies, on the contrary, are negative factors in this context, but they also encourage subjects of the right to apply for notarized transactions to protect their property and secure performance of obligations with contractors. To achieve this goal, the domestic legislator would seem to make more efforts to optimize the digital design of this study, because in the analysis of the problem the authors concluded that in the tectonic transformation of the socio-digital economy and legal relations the issue of electronic transactions requiring a notarial certificate, needs further involvement of both applied and scientific-theoretical 
research, as well as the development of practical solutions and proposals for further improvement of the system of such electronic collaboration.

\section{REFERENCES}

Axelrod, Barry, Robert Durst, Kevin Hunter, Leon Pintsov, William Hart and Morton Silverberg. 1989. "Mail preparation system". Retrieved November 20, 2020 (https://patentimages.storage. googleapis.com/pdfs/US4800505.pdf)

Bondareva, Mariia. 2006. "Anglo-Saxon notary: features of organization and functioning". University Scientific Notes 34(19-20): 153-159.

Chernysh, Volodymyr. 2013. "Notary of Ukraine on the way to European and international standards". Legal Ukraine 2: 2125.

Chyzhmar, Kateryna and Hanna Demkina. 2012. "Legal status of a notary in the process of state registration of real rights to immovable property and their encumbrances under the legislation of Ukraine". Bulletin of the Ministry of Justice of Ukraine 9: 6-15.

Daryanti, Eka. 2018. "The responsibility of notary agreement of the truth under hand notarized as evidence in the process of trial in court". Journal Akta 5(2): 503-508. https://doi.org/10.30659/akta.v5i2.3223

Das, Ankush, Stephanie Balzer, Jan Hoffmann and Frank Pfenning. 2018. "Resource-aware session types for digital contracts". Proceedings of the ACM on Programming Languages 1. https://doi.org/10.1145/3236786

Dyakovych, Myroslava. 2014. "Notary as a state registrar of real estate rights under the laws of Ukraine". Bulletin of the Ministry of Justice of Ukraine 7: 73-77.

Fursey, Svitlana. (Ed.). 2012. Theory of the notarial process: Scientific and practical manual. Kyiv: Alert.

Junyi, Mykhailo. 2020. "Notary according to civil law and common law that related strongly with international civil transactions". Journal Akta 7(3): 285-292. https://doi.org/10.30659/akta.v7i3.11279

Komarov, Viacheslav. 2012. "Ukrainian notary: prospects for development". Bulletin of the Ministry of Justice of Ukraine 3(63): 155-156.

Kuzminskaya, Oksana. 2018. "Electronic notary". Retrieved November 19, 2020 (http://dspace.onua.edu.ua/bitstream/ handle/11300/10054/9_\%d0\%9a\%d1\%83\%d0\%b7\%d1\%8c $\% \mathrm{~d} 0 \%$ bc $\% \mathrm{~d} 0 \%$ bd $\% \mathrm{~d} 1 \% 81 \% \mathrm{~d} 1 \% 8 \mathrm{c} \% \mathrm{~d} 0 \% \mathrm{ba} \% \mathrm{~d} 0 \% \mathrm{~b} 0350-$ 352.pdf? sequence $=1$ \&isAllowed $=y$ ).

Law of Ukraine No. 2155-VIII. 2017. "On electronic trust services". Retrieved November 23, 2020 (https://zakon.rada.gov.ual laws/show/2155-19\#Text).
Law of Ukraine No. 537-V. 2007. "On basic principles of information society development in Ukraine for 2007-2015". Retrieved November 24, 2020 (https://zakon.rada.gov.ua/laws/ show/537-16\#Text).

Law of Ukraine No. 675-VIII. 2015. "On electronic commerce". Retrieved November 26, 2020 (https://zakon.rada.gov.ua/ laws/show/675-19\#Text).

Law of Ukraine No. 851-IV. 2003. "On electronic documents and electronic document management". Retrieved November 25, 2020 (https://zakon.rada.gov.ua/laws/show/851-15\#Text)

Marchenko, Volodymyr. 2020. "Some issues of introduction of enotary system in Ukraine". Prykarpattya Legal Bulletin 1(30): 42-46.

Nelin, Oleksandr. 2012. "Notary and quasi-notary in Ukraine: Some debatable issues". Legal Ukraine 8: 19-22.

Pashkivska, Tetiana. 2013. "Electronic notary": the need is ripe". Legal Newspaper 13: 8-10.

Petrenko, Volodymyr. 2018. "Problems of legal regulation and use of electronic court". Retrieved November 26, 2020 (http://dspace.onua.edu.ua/bitstream/handle/11300/9503/Pet renko\%2041-49.pdf?sequence $=1$ \&isAllowed=y)

Report on the Work of State and Private Notaries. 2020. Retrieved November 23, 2020 (https://minjust.gov.ua/m/zvit-pro-robotuderjavnih-ta-privatnih-notariusiv)

Riva, Alberto, Kenneth Mandl and Daniel Nigrin. 2001. "The personal internetworked notary and guardian". International Journal of Medical Informatics 62(1): 27-40. https://doi.org/10.1016/S1386-5056(00)00136-2

Sant'Anselmo, Robert. 2018. Digital signatory and time stamping notary service for documents and objects. Chatsworth: Robert Sant' Anselmo, Inc.

Shkitin, Yurii (Ed.). 2008. Notary in Ukraine. Kyiv: KNT.

Spasibo-Fateeva, Inna. 2013. "Registration, its significance and consequences (review analysis of Ukrainian legislation)". Pp. 147-160 in Problems of Registration of Rights, Fixation and Certification of Legal Facts of Civil Law. Moscow: Statut.

The Global State of Information Security. 2018. Retrieved November 29, 2020 (https://www.pwc.com/us/en/services/consulting/ cybersecurity/library/information-security-survey.html).

Unified State Register of Court Decisions of Ukraine. 2015. Retrieved November 30, 2020 (https://reyestr.court.gov.ua/Review/ 43500210)

Zaika, Yurii. 2006. "Forms of will: ways of improvement". Bulletin of the Academy of Advocacy of Ukraine 1: 47-52.

Zhuzhzhalov, Mykhailo. 2013. "Requirement for state registration of the transfer of ownership". Pp. 63-64 in Problems of Registration of Rights, Fixation and Certification of Legal Facts of Civil Law. Moscow: Statut.

Received on 01-01-2021

Accepted on 25-01-2021

Published on 02-02-2021

DOI: https://doi.org/10.6000/1929-4409.2021.10.50

(c) 2021 Khomenko et al.; Licensee Lifescience Global.

This is an open access article licensed under the terms of the Creative Commons Attribution Non-Commercial License (http://creativecommons.org/licenses/by-nc/3.0/) which permits unrestricted, non-commercial use, distribution and reproduction in any medium, provided the work is properly cited. 